\title{
Multi-grade Teaching impact in Extended Classroom
}

\author{
Suren Pradhan
}

\author{
Ugyentse Primary School, Bhutan \\ Received: 13 Nov 2021; Received in revised form: 27 Dec 2021; Accepted: 08 Jan 2022 \\ C02021 The Author(s). Published by TheShillonga. This is an open access article under the CC BY license \\ (https://creativecommons.org/licenses/by/4.0/)
}

\begin{abstract}
This journal was to explore and encourage the teachers of my school, how "The Multi-grade Teaching" have the impact on teaching in our lower classes where we have a smaller number of children. The journal was carried out to design and explore collecting the information from one of the Extended Classroom in the catchment area of my school.

The study reveals that the teachers and students require extra time to work hard beside the actual normal classes. It provides significant implications with the professional support needed by the teachers while dealing with classes by a single teacher. There is a need for teachers to be very active, professionally trained to handle the students learning to bring the better result. Based on my study, suggestions have been made that might help our future educationists, teachers and parents. I also come across that parent's involvement is vital in order to support the classroom with a single teacher handling the classes.
\end{abstract}

Keywords - Multi-grade teaching, MGT in Bhutan, MGT in rural Bhutan, Learning in Himalayas, Lhotsampas, Bhoteykharka, Dzongkha, Adebasay.

\section{INTRODUCTION}

"Multi" means plenty, many, or more than one and "grade" means level. Multi-grade, therefore, means many levels. Applied to the educational setting, Multi-grade Teaching is a situation in which one teacher teaches many grades, all at the same time. In other words, it refers to a classroom teaching in which learners of two or more adjacent grade levels are taught in one classroom by one teacher for most, if not all the day (Birch \& Lally, 1995). Similarly, Pridmore (2007) defines Multi-grade Teaching (MGT) as a situation in which one teacher teaches learners of two or more grade levels during one time-tabled period, usually in the same classroom (p. 559).

The children in primary and community schools have a well-established rural tradition in many countries, including Bhutan. In the majority of small rural schools, there may be several grade levels in one classroom taught by one teacher, hence multi-grade. Small schools have been established and organized in this way because of the need for children in remote, isolated and scattered communities to have access to schooling. Multi-grade teaching was introduced in 1991 to address issues of distance-to-school in mountainous rural and remote Bhutan in order to access to primary education (Maxwell, 2012; Strawbridge, 1994).

Bhutan has been practicing multi-grade teaching for past two decades and there are lots of factors that a teacher considers in a multi-grade class room. The two teacher education colleges provide a module for multi-grade teaching in one of the semesters which lays the foundation and the teacher explores the beauty later in the teaching field.

A successful multi-grade classroom and teaching comprises of lots of factors and strategies that the teacher adopts. The teacher needs to plan the setting, organize, be creative, bring resources, do well planned teaching, assess and evaluate the learners. A teacher shouldering the roles of two or more teachers is an amazing thing.

\section{Classroom Organization}

One of the important aspects in multi-grade teaching is the classroom organization which directly influences students' learning. The way things are arranged around children plays an interesting role in learning and attention. "Little we get distraction, greater the comprehension."

\section{Classroom planning}

There are numerous things a teacher should keep in mind while planning. Since multi-grade teaching is done in rural areas, conditions of most of the Bhutanese rural classrooms are challenging and the teacher needs a lot of proper planning. Keeping in mind the categories of three different centers, which is an integral part of multi-grade classroom setting the teaching space needs to be designed accordingly. In every multi-grade classroom, having a well 
distinguished learning center, an activity center and a subject resource center plays a vital role both for classroom organization and classroom management.

I have seen couple of multi-grade classrooms and worked as multi-grade teacher for almost fifteen years in the remote schools of Mongar and got an opportunity to visit Armidale, Australia in 2001 to see and learn a lot about multi-grade teachings. I am lucky to have joined this year to Samtse Dzongkhag, Ugyentse Primary School where I had the opportunity to visit ECR at Bhoteykharka. The teacher had a good management practice in dealing with multigrade teaching learning which I visited in the beginning of 2021. I saw a multi-grade classroom was well organized by a single teacher. The school was a community based located in a remote place where stationery and materials were hardly available. Despite the difficulty in availability of resources, the classroom was a result of teacher's creativity and hard work. The classroom was for grade PP, I and II.

\section{Description of the classroom organization}

Firstly, the classroom at its first sight was such a feast to the eyes. The wall colour and all the other assets were worth seeing. The classroom had a well settled learning center which was located slightly in the left corner of the room. The teacher had made quite a spacious classroom by using the next room which was used as mini store. The rooms were thoughtfully used which was handy as his classroom looked beautiful and spacious too. The learning center was characterized by a U-shaped arrangement where students of same grade was seated in each line and in front of their desk was their names and class (the teacher sometimes changes the seating arrangement according to his lesson activities, so he keeps the students' name and class tag in front of the desk for students to know his/her seats). I was just awed to see how a teacher makes things happen for his students. There were two boards, one green board was stationed in the middle of the students' seats which could be viewed by every student in the class. And another was a portable white board which was donated by a group of civil servants of the village. The teacher uses this board for follow up activities. He said that having the portable board really helped him in teaching and also monitoring students' activity. The teacher table was located to left of the green board which neither distracted students' attention nor the movement. A rack made of wooden planks which contain students' notebooks kept near the teacher's desk. The teacher could access to any book of the students without having to move and make unnecessary movement which might distract students' attention. The learning center was a big hit for me.

The activity center was located on the right side of the classroom, which extends to the extreme end of the classroom. The activity center was divided into small corners which played its effective role. It had corners like discussion corner, art corner, construction corner, reading corner and nature corner. In the activity corner, the teacher had kept two tables which could accommodate four students in each table. This was where the students did the activity when asked by the teacher. I still remember what the teacher said about this center. It was the most effective part of the classroom because the students really liked to discuss and share their ideas in groups. And, this was where they performed their magic. Center is found conducive as the teacher had created. The activity center was decorated with the chart and works done by the students. As soon as the teacher assigns activity to one of the grades students, they silently move to the center and do the activity. The teacher at the end of the week makes each student to see what are the things pasted on the wall and appreciate their own work with merit certificate awards for further improvement.

The reading corner was where students read. They could pick any book from the book rack and enjoy. The wall of the corner also had informative charts with pictorial interpretations. The art corner was full of beautiful drawings by the students. The teacher made sure to paste the drawings drawn by the students. They loved to see their art on the walls. The corner had crayons, colour pencils and water colours. The students loved to work with colours. This was the corner for artist in making and creative minds.

A subject area resource center is an area where student resources relating to a specific subject are located. The classroom didn't have a well-defined subject area resource center but the other corners which the teacher created sufficed the purpose of the subject area resource center. Corners like reading corner where colourful and insightful, books were kept served the best subject area resource center. The shelves had books where the students could find information related to their subjects.

\section{Planning}

A multi-grade classroom requires a lot of planning and patience. The initial start is always a tough one. Putting all the ideas into action requires a good amount of time and patience. All the multi-grade teachers I have met so far have said that planning plays an important part for smooth going of works. It is toughest when they have small space for multi-grade classroom as there are so many things to be kept on good place. Small space often creates distraction between the classes.

The activities the teacher designs should always match the classroom organization. If the teacher has two activities that requires the students from two grades to use activity center, there would be chaotic situation in the classroom. In the Bhutanese classrooms, we usually do not 
have enough space to create a good multi-grade classroom; however, the teacher plays their trick and make it happen. For an instance, to have effective learning the teacher designs the activities in such a way that no students are distracted from each other. If one grade uses the activity center, other uses the reading corner and the third one uses the learning center.

One of the teachers also said that, the places where the students' bag and lunch boxes are kept are very important. These are the things that distract them the most as they are young children who love to ponder around their belonging.

\section{Instructional Delivery and Grouping}

A teacher in his lesson planning mostly plans on how to deliver the lesson to the students and what type of activity should be given and how that should take place whether in groups or individual.

Delivery of lesson and instruction happens in two ways as mentioned in the book that are recitation and discussion. In multi-grade classroom in Bhutan teacher uses both instruction delivery, depending on the content of the lesson. Recitation tends to work best with factual or convergent type of information and with students of same ability. In most of cases in Recitation delivery the most responses are given by the smart students. This is where the teacher does its magic to let all the students participate. Questions can be posed grade wise or to all if in introductory part. The teacher can also pose questions individually to let students feel everyone is included in learning.

Discussion is the most effective way to teach lessons and also engage students in learning. Discussion uses well thought-out, divergent questions aimed at perplexing students, in order to stimulate thought and conversation. This form of learning is comprehensive for the students as they can put their thought on the table as there is no correct answer. A teacher can always conclude the decision with the most appropriate answers and give credit to students for their ideas and thoughts. I feel that in multi-grade classroom 'Discussion' is most effective as the teacher can design activities for different grades which include them to have discussion involving the use of different corners. While two grades are engaged in discussion the teacher can do teaching with the other grade.

I have seen a teacher using discussion method to teach all three grades having the appropriate subject topic alignment. For an example, topics like; match the colours for grade PP, read and colour the fruits for grade 1 and read and colour the body parts for grade 2 can be taught together. The teacher can discuss the names of the colours by letting the students to discuss the things with different colours and at the end make them show their findings. After that the teacher can assign their individual grade activity. Students would enjoy more when the teacher adopts different methods of teaching. This is one way that can help students work along with other grades.

The topic I loved reading from the book was the Practice Model of Instructions because I could relate it much to my own experiences and knowledge. In this model, two areas focused are Learning Environment and the Learning Activities.

I really could relate the six essential variables affecting the learning environment. Teacher authority, task orientation, positive expectation, student cooperation and accountability, non-negative affect and established structure are the six essential variables which plays a bigger role in the individual level of students' lives.

Positive expectation is what a teacher needs to assure the students. This is important for single grade classroom and most important in multi-grade classroom because a single teacher needs to attend to all the requirement of the grades. A teacher can let the students know the positive expectation from the teacher. A teacher expecting good quality work and letting them know they all can do is a different kind of happiness a student can feel. Student's motivation to learn is at peak when their teacher believes in them. A multi-grade teaching would result into fruitful learning if teachers have positive expectations from the students.

The book states, "Teacher who expects students to work together and cooperate on academic tasks produce higher student performance than teachers who do not emphasize cooperation."

Students' cooperation is the key for success of the teacher's designed activities. In Bhutanese multi-grade classroom, most of the activities are oriented with discussion in groups, pairs and whole class which enhances students' cooperation and accountability. Students should be given the responsibility for their own learning. If students are instilled the value of cooperation from such a young age there would be no difficulty in their later grades. The multigrade classroom corners are the main areas where students can what their cooperation skills. No wonder teachers come up with so many interesting activities with the use of various corners.

\section{Grouping as an instructional strategy}

Grouping is one of the strategies for effective learning for the students. In grouping for learning, teacher considers the needs of both individuals and group. Teacher groups the students into whole group, large group, small group, pairs or individual. 
Multi-grade classroom grouping is same like the single grade classroom if the learning activities are for a grade only. Heterogeneous grouping or the mixed-ability grouping is the most effective way to maximize students' success. This is the way to engage all the students and also this gives the opportunity for low achievers to learn from other peers. In a multi-grade classroom, teacher can sometime frame an activity which includes all the grade students and do heterogeneous grouping.

In one of my multi-grade teaching observations of a trainee of Paro College of Education, she had brought grade five and six together and grouped them heterogeneously in four groups of 4 or 5 members. Each group had different ability students and also from different cultural background from both the grades. She assigned them an activity where they had to talk about two different festivals in Bhutan (Social Studies topic). He was pretty obvious that the grouping he had done would result into discussion of one Buddhist festival and another Hindu festival celebrated by Lhotsampas. He was satisfied when the students had written on the two different festivals. With this grouping, students had the opportunity to learn from each other and learn others culture. This shows the beauty of cooperative learning and grouping styles.

One of the multi-grade class teachers said that the students loved reading in pairs. Knowing the interest of students is important for the multi-grade teacher as they can use students' interest and talents in learning too. Teacher can group students into pairs or groups of three for partner reading and choral reading. The teacher said that he let the student who is passionate about drawing to give some tips in groups to the students in their art class. This way of grouping helps teachers in lesson delivery and also interlearning is promoted.

\section{CONCLUSION}

The e-book given to us for reading brought such an enormous reflection to me on the practices on the multigrade teachings in Bhutan. I could recollect all the multigrade classes I have taught during 90's, seen and thus, helped me to reflect in this assignment for the promotion purposes to P1. All the topics were so relevant on multigrade knowledge but to reflect on our own Bhutanese classroom, it made me realize the efforts of one's knowledge and hard work to achieve a well-designed multigrade classroom.

Given a chance there would be few teachers who would opt to teach multi-grade classroom as it requires so much of time and dedications. The chapters I read made me go through in-depth knowledge on the classroom organization, and instructional delivery and grouping. The details reflected on the book and the current scenarios were so much similar and the efforts put in by our multi-grade teachers well deserve for the all praises to be made.

I would also take opportunity to teach and experience multi-grade teaching if I ever get a chance to do. There is so much charm and happiness to do something new for me like multi-grade teaching and I am working on action research too "How can we manage to improve teaching learning of Adebasay at Ugyentse" (Native Black People here in the boarder). Having read and reflected on the Bhutanese practices of multi-grade teaching I have got so much of knowledge and insights which I would again continue multi-grade teaching. If not the ideas of so many corners which plays a vital role not only in multi-grade classes but also can be used in a single grade classroom with high class strength of different ability child.

In nutshell, a multi-grade teaching and classroom is not a piece of bread on the table. The class to work in a good flow requires a lot of planning and hard work. After all the setup of the class, the teacher needs to have good learning activities and classroom management. This is where the lesson delivery and grouping play a vital role. These are some of the interesting topics I hooked from the book I read.

\section{REFERENCES}

[1] Anderson, R.H. (1993). The return of the nongraded classroom. Principal,72(3), 9-12

[2] Dorji, J. \& Easley, S. (2005). Quality of Education in Bhutan - The Story of Growth and Change in the Bhutanese Education System. Thimphu, Bhutan: KMT Press.

[3] Education Sector Review Commission. (2008). Education Without Compromise. Thimphu, Bhutan: Royal Government of Bhutan, Council of Ministers.

[4] Fullan, M. (1993). Change Forces. London: Routledge Falmer.

[5] iDiscoveri Education and the Royal Education Council, Bhutan. (2008). The Quality of School Education in BhutanReality and Opportunities. Thimphu, Bhutan: REC.

[6] Laird, D.J., Maxwell, T.W. and Tenzin, W. (1999). INSET Project Report. Thimphu, Bhutan: INSET.

[7] Maxwell, T., Laird, D., Namgay, N., Ried,J., Laird, J. \& Gyamtso, D. (2006). Focus on student learning outcomes: Report of the review of the Bachelor of Education (Primary) in Distance Education mode in-service programme, Thimphu, Bhutan: INSET

[8] Namgyel, S. \& Heijnen, E. (2005). Researching Pre-Service Teacher Education: Moments of Truth. Report of the Support for Teacher Education Program (STEP). Thimphu: Royal University of Bhutan and NIE's. 